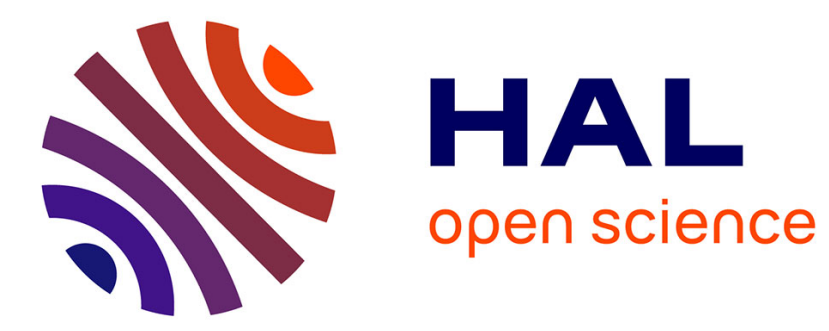

\title{
Austronesian and Chinese words for the millets
} Laurent Sagart, Tze-Fu Hsu, Yuan-Ching Tsai, Yue-Ie Hsing

\section{To cite this version:}

Laurent Sagart, Tze-Fu Hsu, Yuan-Ching Tsai, Yue-Ie Hsing. Austronesian and Chinese words for the millets. Language Dynamics and Change, 2017, 7 (2), pp.187-209. 10.1163/22105832-00702002 . hal-03146013

\section{HAL Id: hal-03146013 \\ https://hal.science/hal-03146013}

Submitted on 18 Feb 2021

HAL is a multi-disciplinary open access archive for the deposit and dissemination of scientific research documents, whether they are published or not. The documents may come from teaching and research institutions in France or abroad, or from public or private research centers.
L'archive ouverte pluridisciplinaire HAL, est destinée au dépôt et à la diffusion de documents scientifiques de niveau recherche, publiés ou non, émanant des établissements d'enseignement et de recherche français ou étrangers, des laboratoires publics ou privés. 


\title{
Austronesian and Chinese words for the millets*
}

\section{Laurent Sagart}

Centre de Recherches Linguistiques sur l'Asie Orientale/Centre National de la Recherche Scientifique

laurent.sagart@gmail.com

Tze-Fu Hsu

Academia Sinica

ecorv@gate.sinica.edu.tw

Yuan-Ching Tsai

Academia Sinica

botsai@gate.sinica.edu.tw

Yue-Ie C. Hsing

Academia Sinica

bohsing@gate.sinica.edu.tw

\begin{abstract}
After reviewing recent evidence from related disciplines arguing for an origin of the Austronesian peoples in northeastern China, this paper discusses the Proto-Austronesian and Old Chinese names of the millets, Setaria italica and Panicum miliaceum. Partly based on linguistic data collected in Taiwan by the authors, proposed ProtoAustronesian cognate sets for millet terms are re-evaluated and the Proto-Austronesian sets are identified. The reasons for the earlier confusion among Old Chinese terms for the millets are explained: the Austronesian term for Panicum miliaceum and one of the Chinese terms for the same plant are shown to obey the sound correspondences
\end{abstract}

* This is a reworked version of a paper presented at the Symposium on Dispersion of People, Crops, and Language: Focusing on Millets in Asia, Tachikawa, Japan, March 20-21, 2014. Work by the first author is part of the program Investissements d'Avenir, overseen by the French National Research Agency, ANR-1O-LABX-0o83 (Labex EFL). We are grateful to three anonymous reviewers for their valuable comments. 
between Proto-Austronesian and Chinese, earlier described, under a particular resolution of the phonological ambiguities in the oc reconstruction. Possession of the two kinds of millets (not just Setaria, as previously thought) places the pre-Austronesians in northeastern China, adjacent to the probable Sino-Tibetan homeland.

\section{Keywords}

Taiwan - Austronesian linguistics - Chinese linguistics - millet - East Asian agriculture - neolithic archaeology - linguistic reconstruction

\section{Background and goals}

Earlier writers have linked the origins of the Austronesians with the domestication of rice, Oryza sativa, and suggested that the members of neolithic ricecultivating communities in the lower Yangtze, such as Hémǔdù in Hangzhou Bay, spoke a precursor language of Proto-Austronesian. Blust (1996) adheres to this view. In an attempt at explaining East Asian linguistic prehistory along the lines of Benedict's theory (Benedict, 1942), which treats Tai-Kadai and Austronesian as two branches of a single 'Austro-Tai' language family, Blust equates these lower Yangtze neolithic settlements with the putative AustroTai homeland. He further relates his lower Yangtze neolithic Austro-Tai entity with the rice-cultivating Austroasiatic cultures, assuming the center of East Asian rice domestication, and putative Austric homeland, to be located in the Yunnan/Burma border area. Under that view, there was an east-west genetic alignment, resulting from a rice-based population expansion, in the southern part of East Asia: Austroasiatic-Tai-Kadai-Austronesian, with unrelated SinoTibetan occupying a more northerly tier.

Discordant with that model, based on sound correspondences in the basic vocabulary and morphological parallels, Sagart (1993) argues for a north-south genetic relationship between Chinese and Austronesian. Sagart (2005) expands this into an argument for Sino-Tibetan-Austronesian relatedness. Integrating the parallel drawn by Fogg (1983) between Setaria italica (foxtail millet) cultivation among the early Chinese and the Formosan Austronesians, Sagart (1995) argues that the ancestral group possessed domesticated foxtail. Based on the cooccurrence c. 65 оо вр in the Shandong Dawenkou culture of foxtail cultivation and of the custom of ritual tooth ablation, both elements also strongly attested in the earliest Formosan neolithic c. 4800-430о в P, he locates the Sino-Tibetan-Austronesian homeland in Shandong. Sagart (2005) argues 
that the Chinese, Tibeto-Burman and Proto-Austronesian terms for Setaria italica are cognate, in that they obey the Sino-Tibetan-Austronesian sound correspondences described in the same paper. Sagart (2008) presents the preAustronesian population movement from Shandong to Taiwan as an expansion of Setaria italica farmers. Under this general model no special proximity exists between the Austronesian and Austroasiatic language families; neither are TaiKadai and Austroasiatic particularly close. Sagart (2004) recognizes a genetic relationship between Austronesian and Tai-Kadai but argues from shared innovations in the numeral system that Tai-Kadai is an Austronesian subgroup coordinate with Malayo-Polynesian, ${ }^{1}$ making Benedict's Austro-Tai family superfluous.

Recent evidence from outside of linguistics has tended to support the northsouth model over the east-west one. In population genetics, Ko et al. (2014) point out that the exclusively Austronesian mtDNA E-haplogroup and the largely Sino-Tibetan Mga haplogroup are twin sisters, indicative of an intimate connection between the early Austronesian and Sino-Tibetan maternal gene pools, at least. Their study of the ancient DNA of 'Liangdao man,' a male burial dated to c. 8000 вр, discovered at the base of a shell mound in Liang island off the north Fujian coast not far from northern Taiwan, has put the oldest known exemplar of the E-haplogroup along the maritime route between Shandong and Taiwan, close to the latter. Together, these observations lead Ko et al. to accept Sagart's view of an origin of the pre-Austronesians in the milletcultivating areas of north China, followed by a north-to-south coastal migration to Taiwan.

Even more solidly, archaeology has supported the north-south model. First, charred grains of millet and rice have been excavated in Nan Kuan Li East, a neolithic site in southwestern Taiwan dated c. 4800-430о вP (Tsang, 2005): grains of Setaria italica, a domesticate otherwise unknown in south China or the Yangtze valley, have been reliably identified among the plant macrofossils there. Additionally, Hsing (2014) finds important amounts of grains of broomcorn millet (Panicum miliaceum) in the Nan Kuan Li East material. The distribution of Panicum miliaceum on the Chinese mainland is even more northerly than that of Setaria italica. All three cereals-Setaria italica, Panicum miliaceum, rice-are cultivated by the modern Austronesians in Taiwan: the evidence from Nan Kuan Li East shows for the first time that their presence in

1 Blust (2014) criticizes some of the numeral etymologies proposed by Sagart but cannot explain the nestedness of the numerals $5^{-10}$, which is crucial to the proposed position of Tai-Kadai. 
Taiwan goes back at least to the mid-third millennium BCE. ${ }^{2}$ This confirms linguists' conclusions that terms for these plants existed in Proto-Austronesian (Blust, 1988 for rice and Setaria italica; Tsuchida, 1976 for Panicum miliaceum). Second, evidence for millets in the Yangtze Valley has to this day failed to materialize, ${ }^{3}$ even though numerous archaeological investigations of early Yangtze Valley agriculture have been carried out in recent decades because of the area's known involvement in rice domestication-and despite the fact that these investigations increasingly rely on flotation to target not only cereal grains preserved in soil, but also tiny by-products of agriculture such as spikelet bases. Third, archaeology has established the existence in northeastern China, especially in Henan and Shandong, of a series of sites in the range of 800о-6ооо в where the same trio of grains has been recovered as in Nan Kuan Li East (Stevens and Fuller, 2017). Although the cultivated status of the grains at the earlier sites is open to question, the recurrent association of Setaria italica, Panicum miliaceum and morphologically primitive rice well in advance of the Austronesian settlement of Taiwan makes northeastern China a much more likely source of early Austronesian agriculture than the lower Yangtze. Fourth, archaeology has remained stubbornly silent on the subject of a center of rice domestication in the upper Burma/Yunnan region. The earliest dates for rice cultivation there postdate those in eastern China by several millennia. Thisand the total absence of shared rice vocabulary between Austronesian and Austroasiatic - casts doubt on the reality of the rice-domestication connection in Blust's version of Austric. These developments have made a northern Chinese origin of Austronesian agriculture increasingly attractive to archaeologists (Bellwood, 2008 [2005]; 2013: 189; Fuller, 2011; Stevens and Fuller, 2017).

In this paper we look at linguistic aspects of early millet cultivation in East Asia. The two principal East Asian millets, Setaria italica and Panicum miliaceum, are widely thought to have been domesticated in north China. The presence of their names in the reconstructed Proto-Austronesian vocabulary and of their fossils in the earliest Formosan neolithic, together with their absence in south China, including the Yangtze valley, at the time of the first settlement of Taiwan strongly suggest that the Setaria-based population movement out of Shandong proposed in Sagart (2008) is not only real, but also involved both millets rather than just Setaria. This leads us to ask whether, as with Setaria italica, the Sino-Tibetan and Austronesian names of Panicum miliaceum are

2 Gray et al. (2009) estimate the date of Proto-Austronesian at c. 323 все.

3 Except in Chengtoushan in the central Yangtze, c. 3900 вСE. Setaria italica there is generally regarded as a northern intrusion. 
relatable through sound correspondences. This paper investigates this particular issue. More generally, we clarify the proposed reconstructions for the names of the millets separately in Proto-Austronesian and in Old Chinese. On the Austronesian side, we weed out cognate sets that are either incomplete or relying on misidentified/borrowed material, wherever possible establishing original semantics. With respect to the Chinese terms, we present the solution to a longstanding puzzle that has obscured the meanings of the main designations of the millet plants.

As a preliminary step, we considered it necessary to gain an accurate picture of the vocabulary of millet cultivation among the modern Austronesians in Taiwan, especially as earlier material is not completely reliable as regards plant identification. To that end, a multidisciplinary team consisting of the first author, a linguist, and the second and third authors, two botanists, visited Rukai, Paiwan, Puyuma, Atayal, Sediq, Bunun, Thao, Tsou, Kanakanabu, Saaroa, Amis and Kavalan villages in Taiwan to collect such vocabulary in May 2013 and December 2014. Correct identification of the plants was ensured by presenting agriculturally experienced language informants with herbarium samples of Setaria italica and Panicum miliaceum (panicles, seeds, stems and leaves), as well as of Chenopodium formosanum (台灣莍) and of the small-seeded Taiwan oil millet Eccoilopus formosanus ${ }^{4}$ (台灣油芒), with which confusion is possible. Vocabulary relating to other domesticates (rice, beans etc.) was also collected. Wherever possible, identification of plant names was completed by in situ observations of growing plants and their grains. This paper is based in part on that material.

Aside from recent introductions like maize, finger millet Eleusine coracana and barley, the modern Austronesians in Taiwan cultivate foxtail millet Setaria italica, broomcorn millet Panicum miliaceum, rice Oryza sativa, sorghum Sorghum bicolor, the Taiwan oil millet Eccoilopus formosanus (a.k.a. Spodiopogon formosanus, 台灣油芒) and a chenopod Chenopodium formosanum (台灣蓩). Setaria italica is ubiquitous and has major cultural importance: its cycle forms the basis of the calendar and festivals are held to ensure success in its cultivation. The plant's spirit is venerated. There are both glutinous and nonglutinous varieties. Glutinous varieties are used in making millet cakes (Japanese mochi) and wine. Panicum miliaceum is less widespread than Setaria, being now cultivated only by the Saisiyat, Atayal, Sediq and Bunun. Rice was traditionally either grown in floodable areas without artificial irrigation or in upland swiddens. The irrigated rice field was introduced at Chinese contact: terms for

4 Also referred to as Spodiopogon formosanus in the literature. 
TABLE 1 Evidence for Proto-Austronesian *beCey 'Setaria italica.' The term 'Panicum italicum' used by Blust is a synonym of 'Setaria italica.'

Proto-Austronesian *beCey millet sp., probably foxtail millet: Setaria italica

Formosan

Saaroa

ebeceye millet

Rukai (Tanan) beceye millet

Proto-Malayo-Polynesian *betey millet sp., probably foxtail millet: Panicum italicum

\begin{tabular}{lll} 
Buginese & wettey & millet \\
Bimanese & witi & millet \\
Rotinese & bete $(k)$ & millet \\
Tetun (Luka) & fotan & a variety of millet \\
Erai & hetan & millet \\
Asilulu & heten & millet (Panicum spp.) \\
Kayeli & betene & foxtail millet \\
Buruese & feten & foxtail millet: Panicum italicum \\
\hline
\end{tabular}

SOURCE: BLUST AND TRUSSELL (ONGOING), SIMPLIFIED

'irrigated rice field' in many Formosan languages are borrowed from Minnan Chinese. Sorghum bicolor was introduced in historical times from Indianized Indonesia after displacing Panicum miliaceum, often inheriting its name. Both the Taiwan oil millet and Chenopodium formosanum are indigenous domesticates. One use of $C$. formosanum is as a ferment in millet wine. The Taiwan oil millet has been confused with other plants, e.g. Panicum miliaceum, Sorghum bicolor, Echinocloa crusgalli in earlier literature. In the next sections we discuss the Austronesian and Chinese names of Setaria italica (foxtail millet) and Panicum miliaceum (broomcorn millet).

2.1 The Proto-Austronesian name of Setaria italica

Two candidates for the Proto-Austronesian name of Setaria italica can be found in the literature: *beCey and *zawa. The cognate set for *beCey in Blust and Trussel (ongoing) is shown in Table 1. 


$\begin{array}{lll}\text { 1. } & \text { Amis (Dulan) } & \text { lamalu } \\ \text { 2. } & \text { Amis (Matai'an) } & \text { hafaj } \\ \text { 3. } & \text { Atayal (Smakus) } & \text { trakis } \\ \text { 4. } & \text { Bunun (Shuanglong) } & \text { madó } \\ \text { 5. } & \text { Kanakanabu (Namaxia) } & \text { vina? } \\ \text { 6. } & \text { Kavalan (Xinshe) } & \text { luzay 'millet' (there is another term for } \\ & & \text { Panicum) } \\ \text { 7. } & \text { Paiwan (Taiban) } & \text { vaqu } \\ \text { 8. } & \text { Pazeh } & \text { piaxun 'millet' } \\ \text { 9. } & \text { Puyuma (Nanwang) } & \text { dawa } \\ \text { 10. } & \text { Rukai (Dewen) } & \text { betsey } \\ \text { 11. } & \text { Saaroa (Gaozhong Li) } & \text { abəcəyə } \\ \text { 12. } & \text { Saisiyat (Donghe) } & \text { tata? } \\ \text { 13. } & \text { Sediq (Qingliu) } & \text { matsu } \\ \text { 14. } & \text { Thao (Dehua) } & \text { kamar } \\ \text { 15. } & \text { Tsou (Tfuye) } & \text { ton?u }\end{array}$

SOURCES: MAY 2013 AND DECEMBER 2014 FIELDWORK BY THE AUTHORS EXCEPT FOR \#8, FROM LI AND TSUCHIDA (2OO1)

The two Formosan languages with reflexes of *beCey: Rukai and Saaroa, are inland, mountain languages. Large geographical distances separate them from the western and central Malayo-Polynesian languages where the other reflexes of *beCey are found. The fact that sound correspondences exist between these Formosan and non-Formosan forms shows that the modern words in Rukai and Saaroa have been continually in use among these populations since before the out-of-Taiwan event, c. 400 years B P. This makes the suggestion in Tsang (2012) that prehistoric millet cultivation in Taiwan was lost and then reintroduced through contact with other populations untenable. In particular, a reintroduction from Austronesian regions more to the south is excluded: in the Austronesian family, the distinction between the consonants * $\mathrm{t}$ and ${ }^{*} \mathrm{C}$ is only found in Taiwan, both sounds merging as $t$ outside of Taiwan. If the Rukai and Saaroa words for Setaria were loans from a Malayo-Polynesian language, they would therefore reflect *beten rather than *beCen. The same goes for the name of Panicum miliaceum: *baCaR, for the same reasons.

It is interesting that every Formosan language except Rukai and Saaroa has independently replaced *beCen with a local innovation (Table 2). This is in marked contrast to the stability of the Formosan words for rice and Panicum 
miliaceum, which mostly reflect *pajay and *baCaR, respectively. We suggest that the situation with Setaria italica is the result of taboo avoidance. As already mentioned, Setaria italica is of great religious importance to the Formosan Austronesians (as it was to the early Chinese: see Fogg, 1983) and the cultivation and consumption of the plant is marked with numerous taboos, especially at times of festivals. One taboo may have affected the plant's name-hence the frequent replacement of the Proto-Austronesian (PAN) term with locally innovated terms, such as Paiwan vaqu < $\mathrm{PAN}^{*}$ baqeRuH ${ }_{1}$ 'new' (= the new harvest). In our opinion, there is no solid ground for supposing an interruption in cultivation of Formosan Setaria italica since early Austronesian times: the archaeological elusiveness of tiny millet grains in Formosan sites outside of Nan Kuan Li East and a few other early neolithic sites in Taiwan (Niuchouzi, Youxianfang) is due to flotation techniques having been introduced in Taiwan too recently.

The first scientific reconstruction of Proto-Austronesian, by Dempwolff (1934-1938), did not use Formosan evidence. As a result, Dempwolff missed the Proto-Austronesian name of Setaria italica: *beCey. He only reconstructed a nonspecific millet name: *zawa 'Hirse' [millet]. Cognate sets assembled by Blust (1976: 33), Verheijen (1984: 67) and Wolff (2010: 849) add Tagalog and Cebuano dáwa 'millet,' Toba Batak jaba 'kind of grain,' Ngadju Dayak jawe 'millet,' Old Javanese jawa 'grain,' Malay jawa 'millet, barley,' Palembang jawa 'Setaria italica,' Nagé zawa, jawa 'Setaria italica.' The Formosan (Puyuma) form dawa 'Setaria italica,' cited in Blust (1976: 33) as belonging to this set, seems at first glance to point to a Proto-Austronesian etymon with a distribution superficially similar to that of *beCey: a single Formosan word with several apparent Malayo-Polynesian cognates. However, as pointed out in Verheijen (1984), *zawa also occurs in western Malayo-Polynesian languages in other meanings: 'sorghum,' 'maize,' and especially as a determinant, translatable as 'from Java.' Sanskrit introduces a complication: Sanskrit yava means 'barley,' and the toponym Yavādvipa 'barley island' for Java and Sumatra already occurred in Vālmīki's Rāmāyaṇa, an early Sanskrit literary text dated variously from 500 to 100 вСE. Ptolemy of Alexandria $(87-15$ O CE) cited the toponym as 'I $\alpha \beta \alpha \delta$ ío (Geography 7,2,29; Stückelberger and Grasshoff, 2006), explaining its meaning

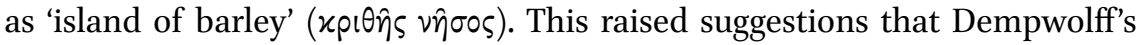
*zawa was an early loan from Sanskrit. However, it would be curious for a culture having an old acquaintance with Setaria italica to replace that plant's name with a foreign term meaning 'barley.' Gonda (1952: 349) has a more subtle interpretation. According to him, jawa was a native Austronesian word meaning 'Indonesian, indigenous' (cf. Javanese jawa 'native, indigenous, common, of little value, natural'). The Sanskrit name Yavādvipa originally meant 'Island(s) of 
Indonesia' but through popular etymology, Indian navigators and colonizers reinterpreted it as 'Island(s) of barley,' the explanation given to Ptolemy. This seems plausible. It implies that there is no meaningful connection between Skt. yava 'barley' and Proto-Malayo-Polynesian *zawa. On this basis, we suggest that the term *zawa 'local, Indonesian' became used as the designation of a specifically Sumatran/Javanese variety of Setaria italica. We propose that this variety, Ngadju Dayak jawe 'millet,' Palembang jawa 'Setaria italica,' Nagé zawa, jawa 'Setaria italica,' spread with its name north to the Philippines (Tagalog, Cebuano dáwa 'millet'), and onward north by a maritime route, to the southeast coast of Taiwan, where it found its way into the Puyuma language as dawa 'Setaria italica.' It is significant that the Puyuma have a tradition of acquiring dawa from the Butul [= Yami] of Orchid Island, off the southeast coast of Taiwan, where Setaria italica is widely cultivated (Cauquelin, 2015). Yami is a Malayo-Polynesian language belonging to the Batanic (or Bashiic) group of the northern Philippines, whose speakers must have migrated to Orchid Island in the not-too-distant past, considering the language's closeness with other Batanic languages. The modern Yami term for the plant Setaria italica is kadai, but rawa $<$ *dawa designates the panicles of Setaria italica: assuming a lexical shift in Yami, this may be the direct source of Puyuma dawa. This leaves *beCey as the only serious candidate for 'Setaria italica' in ProtoAustronesian.

\subsection{The Chinese name of Setaria italica}

The modern standard Chinese name for the plant Setaria italica is gǔzi ${ }^{5}$ 穀子. Outside of the standard language there is much diversity. A form common in the south is sù 粟. Both, however, are innovated: their referent in Old Chinese was not a plant species but grains of cereals, with and without their husks, respectively. The Old Chinese (oc) word for the plant Setaria was 稷, modern Chinese jì [tci 51] ${ }^{6}$ (Chang, 1980; Bray, 1984; You, 1984; Zhang, 1984; Sagart,

5 In citing Chinese forms, we follow these conventions: Old Chinese forms are given in the Baxter-Sagart (2014) reconstruction. They are in IPA, starred, and not italicized. Middle Chinese forms follow the Baxter-Sagart (2014) notation. They are in ASCII, not starred, and italicized. Modern Standard Chinese forms are in pīn-yīn romanization, not starred and not italicized, or in IPA, between square brackets. In Old Chinese reconstructions, square brackets identify ambiguous segments. For an example, see fn. 7. Hyphens separate word-stems from prefixes and suffixes.

6 The numerical expression ' 51 ' following the phonetic transcription inside the brackets notes a high falling tone in a system commonly used by Chinese dialectologists. 
1999), Old Chinese * $[\mathrm{ts}] \partial \mathrm{k}^{7}$ in the system of Baxter and Sagart (2014) ${ }^{8}$ Sagart (2005: 165) observes that it corresponds phonologically to Proto-Austronesian *beCey. As always in Sagart's (2005) system, the part to compare in the Austronesian word is the last syllable, here *-Cey. Sagart (2005) gives examples of the correspondences PAN ${ }^{*} \mathrm{e}-\mathrm{OC}^{*}$, , and PAN ${ }^{*}-\mathrm{n}-\mathrm{OC}^{*}$-k. No example is given of PAN ${ }^{*} \mathrm{C}-\mathrm{OC} *$ ts. Here are two (naturally all sound correspondences interlock with those given in Sagart, 2005):

$\begin{array}{llll}\text { PAN }^{*} \mathrm{kuCuH}_{2} & \text { 'louse' } & \text { OC 蛋 *ts }{ }^{\mathrm{S}} \mathrm{u} \text { ? }>\text { tsaw } X>\text { zăo } & \text { 'flea' } \\ \text { PAN }{ }^{*} \mathrm{kiCin} & \text { 'joint, tendon' } & \text { OC 節 *ts'ik }>\text { tset }>\text { jié } & \text { 'joint' }\end{array}$

The second example shows simultaneously ${ }^{*} \mathrm{C}-{ }^{*}$ ts and ${ }^{*} \mathrm{\eta}-{ }^{*} \mathrm{k}$. For a discussion of the ${ }^{*} y$ - ${ }^{*} k$ correspondence, see Sagart (2016). Two other examples showing ${ }^{*} \eta{ }^{*} k$ are:

\begin{tabular}{|c|c|c|}
\hline $\begin{array}{l}\text { ysey } \\
\text {-geRan }\end{array}$ & $\begin{array}{l}\text { 'stopper, plug' } \\
\text { 'rib' }\end{array}$ & $\begin{array}{l}\text { oC 塞 }{ }^{*}[\mathrm{~s}]^{\mathrm{S}} \mathrm{\partial k}>s o k>\text { sè } \\
\text { oC 助 }{ }^{*}[\mathrm{r}]^{\mathrm{S}} \mathrm{zk}>l o k>\text { lèi }\end{array}$ \\
\hline
\end{tabular}

We will see a third example of PAN ${ }^{*} \mathrm{C}-\mathrm{OC}{ }^{*}$ ts in the word for 'Panicum miliaceum' (below). Probable Tibeto-Burman cognates of the Chinese word for Setaria italica are Trung t6ja?55 'foxtail millet' (Trung Dictionary Committee, 2016) and Lhokpu cək 'Setaria italica' (plant identified and term collected by George van Driem, pers. comm. to Ls, June 24, 2004; not phonologized). ${ }^{9}$

7 The brackets around 'ts' mean that the Old Chinese word began in [ts], or in any other sound which evolves to Middle Chinese like oc *ts. Specifically here, ${ }^{*}$ ts may have been preceded by an extrasyllabic voiceless consonant like ${ }^{*}[\mathrm{p}],{ }^{*}[\mathrm{t}]$ or ${ }^{*}[\mathrm{k}]$, or a minor syllable with a central vowel, like *[pə], *[tə] or *[kə]. Such elements, if they were present, would have left no trace in Middle Chinese.

8 The Old Chinese reconstruction in Baxter and Sagart (2014) is made strictly on Chineseinternal evidence, including Chinese loanwords to neighboring languages. As a measure against circularity, it does not take into account Tibeto-Burman or Austronesian reconstructions.

9 Van Driem's Lhokpu materials are unpublished. From the data we saw in June 2004, Lhokpu $-ə \mathrm{k}=$ Written Tibetan -ag = Chinese *-ək in 'pig' (with Chinese shift to 'riches,' cf. Lat. pecunia < pecu), 'black/evil' and 'Setaria italica' (with wT shift to 'fodder'). The correspondence of initials, Lhokpu c-, Chinese ts- needs to be exemplified but does not appear suspicious. As for Trung, the final correspondence Trung -a? = Chinese *-ək recurs in 'black' and 'weave' (Nujiang Dulong also 'pig'). Trung initial t6- reflects Tibeto-Burman *ts- which is the usual match of Old Chinese *ts-. An unexplained palatalizing context must be supposed in Trung. 
Lhokpu and Trung are not phylogenetically close within Sino-Tibetan. Whether the word reconstructs to Proto-Sino-Tibetan depends on whether Chinese is a primary branch of the family - the standard view. Certain modern authors, in particular in China (Li, 1983: 29; Hu, 1984; Chai et al., 1999) claim that jì 稷 did not refer to Setaria italica in early Chinese but to Panicum miliaceum. This is based on statements by a succession of Chinese authors from c. 950 CE down to modern times to the effect that ji 稷 is the same plant as 穄 *[ts][a][t]s > tsjejH > jì 'Panicum miliaceum.' Thus Chai et al. (1999: 9) observe that in the three provinces of Shandong, Henan and Hebei, (glutinous) Panicum miliaceum varieties are today usually referred to as jì, written as '稷.' However, this is a confusion arising from the phonetic convergence of these two words after Middle Chinese, ${ }^{10}$ a convergence affecting specifically the region of the three provinces referred to by Chai et al. In Modern Standard Chinese, based on the pronunciation of Beijing (in Hebei province), Middle Chinese (MC) 稷 $t s i k$ and 穄 $t$ sjejH are homophones, due to regular convergent evolution:jì [t6i 51]. Their merger had already occurred in northern Chinese during the Khitan, or Liáo 遼, dynasty, which occupied parts of north China, including Hebei, from 916 to $1125 \mathrm{CE}$. Phonetic transcriptions in Khitan small script of the 11th and 12th century Chinese show that while MC final $-k$ was still represented by a glottal stop in poetry, it had disappeared in everyday speech (Kane, 2009: 252 f.). Thus in everyday Chinese of the Khitan period, 稷 'Setaria italica,' MC tsik, was probably [tsi]. At the same time, the character 祭 jì, a MC homophone of 穄 jì 'Panicum miliaceum' in Middle Chinese (both Mc tsjejH) and the phonetic element in 穄 jì 'Panicum miliaceum,' was also [tsi] (Shen, 2014: 318). The earliest ${ }^{11}$ statement equating 稷 $\mathrm{jì} \mathrm{and}$ 穄 jì is in the lexicographical work Shuowen Jiezi Xizhuan by Xu Kai $(920-974 \mathrm{CE})$. It is significant that there are no statements equating 稷 tsik and 穄 $t s j e j H$ from time periods preceding the phonetic merger of the two forms in the north. Thus we can conclude with some confidence that claims that 稷 $t s i k$ and 穄 $t s j e j H$ were variant names of the same plant in early Chinese times are based on a confusion resulting from phonological evolution, and that (since there is no question that ji 穄 referred to 'Panicum miliaceum' in antiquity) textually and ritually prominent ji 稷 (tsik) must be the name of Setaria italica.

10 A standard of literary pronunciation from the late sixth century $\mathrm{CE}$, embodied in the dictionary Qièyùn 切韻, and relatively well understood.

11 Based on the collection of statements on ji 稷 in the literature since antiquity down to modern times in Chai et al. (1999: 16f.). 
TABLE 3 Names of Panicum miliaceum encountered in our 2013-2014 fieldwork

\begin{tabular}{|c|c|c|}
\hline & Atayal (Smakus) & vesinu \\
\hline & Bunun (Shuanglong) & batal \\
\hline & Saisiyat (Donghe) & $a \vartheta c$ \\
\hline & Sediq (Qingliu) & baso \\
\hline
\end{tabular}

The names of Panicum miliaceum (a.k.a. broomcorn millet, common millet, proso millet)

\subsection{The Proto-Austronesian name of Panicum miliaceum}

In the course of our two seasons of fieldwork in Taiwan, we encountered Panicum miliaceum in only four tribes (see Table 3 ).

However, names for panicum miliaceum had earlier been recorded in more languages. Three competing reconstructions have been proposed: Tsuchida's *baCaR, Li's *baSaR and Blust's *baCaj. There is significant overlap in the supporting evidence adduced in their support: unlike *beCey and *zawa, they are disjunct (either/or reconstructions) — only one of them can be valid. The supporting evidence for each is listed in Table 4.

The languages listed in Table 4 are all Formosan except for two MalayoPolynesian languages: Hanunoo (Philippines) and Tetun (Timor). Many more Malayo-Polynesian terms matching one or the other reconstruction could be added; however, none of them refers to Panicum miliaceum: they are all words for sorghum, maize, or other cereals which have replaced Panicum miliaceum.

Tsuchida's 'Proto-Formosan' reconstruction *baCaR 'Panicum miliaceum' (1977: 90), augmented with additions by Li (2004 [1992]: 961, \#99) contains at least one questionable form: Taokas basau. It is doubtful whether *-R goes to - $u$ in Taokas. By Li's rules one should expect Taokas basax, basah, vasax, or vasah. Instead, Taokas basau probably reflects Proto-Austronesian *baSaw 'to let cool off,' a term used especially of cooked cereals. The same is probably also true of Sediq bassau. Here (Table 5) is the supporting evidence for Proto-Austronesian *baSaw, slightly simplified from Blust and Trussel (ongoing; accessed 17 Feb. 2014).

Note the frequent reference to cold rice in the Malayo-Polynesian material. While recording the Atayal vocabulary of millet in Smakus on May 8, 2013, we were told by our Atayal informant that nə-basaw is the name of a variety of 
TABLE 4 Candidate reconstructions for 'Panicum miliaceum' and 'cold, of leftover food' (shaded forms would be categorized correctly in the rightmost column under *baSaw)

\begin{tabular}{|c|c|c|c|}
\hline & $\begin{array}{l}\text { 'Proto-Formosan' } \\
\text { *baCaR 'Panicum } \\
\text { miliaceum' (Tsuchida, } \\
\text { 1977) with additions } \\
\text { by Li (2004 [1992]) }\end{array}$ & $\begin{array}{l}\text { *baCaj 'millet } \\
\text { sp.' (Blust and } \\
\text { Trussel, ongoing) }\end{array}$ & $\begin{array}{l}\text { *baSaw 'cold, of } \\
\text { leftover food' (Blust } \\
\text { and Trussel, ongoing) }\end{array}$ \\
\hline Saisiyat & $\begin{array}{l}\text { basa, vasal 'P. } \\
\text { miliaceum' }\end{array}$ & & \\
\hline Bunun & batal 'P. miliaceum' & & \\
\hline Atayal (Skikun) & bacax & & \\
\hline Atayal (Matabalay) & & basag 'millet' & \\
\hline Atayal (Smakus) & & & $\begin{array}{l}\text { nabasaw 'k.o. Setaria' } \\
\text { (our } 2013 \text { field notes) }\end{array}$ \\
\hline Sediq & bassau & & \\
\hline Rukai (Maga) & bcaa 'P. miliaceum' & & \\
\hline Taokas & basau & & \\
\hline Amis & & & fasaw \\
\hline Kavalan & & & basaw \\
\hline Hanunoo & & bátad 'sorghum' & báhaw \\
\hline Tetun & & batar 'maize' & \\
\hline
\end{tabular}

Setaria italica (note: not Panicum miliaceum!) which is very hot when drawn out of the cooking-pot and must be left to cool off on a leaf before eating. Similarly, among the Kavalans on December 12, 2014, we recorded vasaw 'to let cool off, of cooked cereals in general.' The Sediq and Taokas forms are phonologically regular outcomes of *baSaw 'let cool off' and evidently belong there instead of under *baCaR. Yet even shorn of these two forms, Tsuchida's *baCaR 'panicum miliaceum' retains broad support. One should add to it several Western Malayo-Polynesian forms such as Makassarese batara? 'millet species'12 and

12 Meaning according to Cense's dictionary (Cense and Abdoerrahim, 1979). John Wolff (April 19, 2014) kindly informs me that the earlier dictionary of Matthes (1859) distinguished between batara' 'maize' and batara'-tadjeng 'real millet.' 
Proto-Austronesian *baSaw 'cold, of leftover food; leftovers from a meal'

Formosan

Amis

fasaw

cooled off

Kavalan

basaw

fever went down, abated; to become cold

Proto-Malayo-Polynesian *bahaw 'cold, of leftover food; leftovers from a meal'

\begin{tabular}{|c|c|c|}
\hline \multirow[t]{3}{*}{ Itbayaten } & vahaw & idea of being cold (of food esp.) \\
\hline & ma-vahaw & cool, be getting cold (food, hot water, something once heated) \\
\hline & vahaw-en & let something cool off \\
\hline Ilokano & báaw & left over, cold rice; tepidity, coolness \\
\hline Pangasinan & báaw & cooked rice \\
\hline \multirow[t]{3}{*}{ Bikol } & báhaw & cold, referring only to food once served hot \\
\hline & mag-báhaw & to grow cold \\
\hline & may-báhaw & eat something for breakfast \\
\hline Hanunóo & báhaw & breakfast, the first meal of the day, usually eaten about 10 A.M. \\
\hline \multirow[t]{3}{*}{ Tagalog } & báhaw & left-over food, especially boiled or steamed rice \\
\hline & $i$-báhaw & to set aside food so that it becomes "left-overs" \\
\hline & ma-máhaw & to eat left-over food \\
\hline \multirow[t]{3}{*}{ Aklanon } & báhaw & cold rice; cool off, get cool (said of food) \\
\hline & pa-máhaw & breakfast; snack (so-called because it generally consists of cold \\
\hline & & leftovers, particularly rice); to eat breakfast \\
\hline Masbatenyo & bahaw & leftover food, leftover \\
\hline Binukid & bahaw & $\begin{array}{l}\text { leftover food; lunch, food taken along with one; for food to cool } \\
\text { off; fig., for one's emotions or an emotional situation to cool } \\
\text { down, be pacified }\end{array}$ \\
\hline Mansaka & baaw & food prepared for a trip \\
\hline
\end{tabular}

SOURCE: BLUST AND TRUSSELL (ONGOING), SIMPLIFIED

Tetun batar 'maize,' even though the referent has changed. ${ }^{13}$ We restate the supporting evidence here:

13 On present evidence we are uncertain whether Panicum miliaceum is cultivated at all today in the Austronesian world outside of Taiwan, although it must have been in the past. 
Proto-Austronesian *baCaR 'Panicum miliaceum':

Formosan:

Saisiyat (Ta'ay) basaL 'Panicum miliaceum'

Saisiyat (Tungho) basa: 'Panicum miliaceum'

Bunun batal 'Panicum miliaceum'

Atayal (Skikun) bacax 'Panicum miliaceum'

Rukai (Maga) bcaa 'Panicum miliaceum'

Malayo-Polynesian:

Makassarese batara? 'millet spp.'

Tetun batar 'maize'

In the same paper (Li, 2004 [1992]) that augments Tsuchida's *baCaR analysis, Li presents a distinct 'Formosa-only' reconstruction:

*baSaR 'millet': Atayal [no indication of dialect; perhaps Matabalay] basag, Sediq [apparently Tongan] basaw, Saisiyat [presumably Ta'ay] basaL, Taokas basau.

2004 [1992]: 96o, \#77

However, again the -au rhyme in Taokas does not allow a reliable match with Proto-Austronesian *-aR and should be excluded. The other forms can indeed reflect *baSaR, but considering that Sediq basaw can equally well reflect *baSaw 'to let cool off,' and considering that Li's *baSaR only accounts for part of the material under Tsuchida's * baCaR, the latter should be preferred.

The third candidate for 'Panicum miliaceum' is Blust's *baCaj 'millet sp.' (Blust and Trussel, ongoing, accessed March 2014; see Table 6). ${ }^{14}$

Note that final ${ }^{*}$-j in *baCaj is regarded by Blust as a palatalized voiced velar stop [g] . While Formosan (Atayalic) does point to a kind of millet, the MalayoPolynesian forms consistently refer to sorghum or maize. Based on Cense and Abdoerrahim (1979), Blust glosses Makassarese batara? as 'millet sp.', but Verheijen (1984: 67) says 'sorghum' and, as noted in fn. 12, Matthes says 'maize.' The Malayo-Polynesian evidence in this set is suggestive of the widespread transfer of the name of Panicum miliaceum to sorghum, subsequent to the introduction

14 In a personal communication to Sagart (December 2014) following the presentation of the workshop version of this paper, Blust agreed that *baCaR is the proper ProtoAustronesian reconstruction for Panicum miliaceum, and has removed *baCaj from his online dictionary. However, since the reconstruction *baCaj is still considered valid at the level of Proto-Malayo-Polynesian in a recent publication ( $\mathrm{Li}, 2 \mathrm{2015})$, a refutation remains necessary. 
Proto-Austronesian *baCaj millet sp.

Formosan

\begin{tabular}{|c|c|c|}
\hline Atayal (Matabalay) & basag & millet \\
\hline \multicolumn{3}{|l|}{ Malayo-Polynesian } \\
\hline Hanunóo & bátad & $\begin{array}{l}\text { sorghum, a coarse annual grass, cultivated as a } \\
\text { cereal (Andropogon sorghum Linn. Brot.) }\end{array}$ \\
\hline Cebuano & batád & $\begin{array}{l}\text { sorghum, kind of coarse grass used for forage: } \\
\text { Andropogon sorghum }\end{array}$ \\
\hline Maranao & bantad & Sorghum vulgare pers. - - barley-like plant \\
\hline Makassarese & batara? & millet sp. \\
\hline Tetun & batar & maize \\
\hline Kédang & watar & maize \\
\hline
\end{tabular}

SOURCE: BLUST AND TRUSSELL (ONGOING), SIMPLIFIED

of sorghum from India; and much later to the secondary transfer of the name from sorghum to maize. Sorghum, an east African domesticate (Harlan, 1977), is present in the Indus Valley at c. 3900 BP (Weber, Kashyap, and Harriman, 2010) and presumably spread to Indonesia/Java with Indian influence, well after the Austronesian settling of the western Malayo-Polynesian world.

There are two weaknesses with Blust's reconstruction *baCaj. First, it forces us to dissociate Atayal basag from the rest of the Formosan evidence: the word endings in Saisiyat basaL, Bunun batal, Rukai bcaa, all 'Panicum miliaceum,' point to Proto-Austronesian *-R and are not compatible with ProtoAustronesian *-j. Even supposing that *baCaj was a bona fide Proto-Austronesian word, *baCaR would still have to be reconstructed to account for the agreement between Saisiyat, Bunun and Rukai. Second, the association of the old word for Panicum miliaceum with the more recent cereals sorghum and maize in the western Malayo-Polynesian world introduces the likelihood of language contact interfering with normal phonological transmission: as the new cereal spread across the western Malayo-Polynesian world, its name must have spread with it, so that the apparently correct alignment of the reflexes of Proto-Austronesian *j in the *baCaj set is not necessarily the result of inheritance. The crucial evidence pointing to ${ }^{*}-\mathrm{j}$ in this set, as opposed to ${ }^{*}-\mathrm{R}$ in Tsuchida's *baCaR, comes from final $-d$ in Philippine languages. We suggest, however, that Philippine - $d$ in this word is the result of contact. When sorghum was introduced from India to Sumatra or Java, it replaced Panicum miliaceum, 
Proto-Austronesian *baCaR, whose local name must have been something like batar. And when sorghum was transmitted to the Philippines under the name batar, final $-r$ was interpreted as $-d$ in languages like Tagalog where $-r$ does not occur word-finally. ${ }^{15},{ }^{16}$ This produced an accidental match with the reflexes of Proto-Austronesian *-j (Atayal-g, Malay - $r$, Tagalog- $d$ ), which led Blust to reconstruct *baCaj. Consequently there is no ground for supposing a ${ }^{*}$-j ending in the Proto-Austronesian word for Panicum miliaceum: final *-R and language contact account for all forms. Of *baCaR, *baSaR and *baCaj, then, only *baCaR qualifies for Proto-Austronesian antiquity; and since its Formosan reflexes uniformly mean 'Panicum miliaceum,' it must be the Proto-Austronesian name of that cereal.

\subsection{The Chinese names of Panicum miliaceum}

There is general agreement that 乘 ${ }^{*} \mathrm{~s}-\mathrm{t}^{\mathrm{h}} \mathrm{a}$ ? $>$ syoX $>$ shǔ and 穄 ${ }^{*}[\mathrm{ts}][\mathrm{a}][\mathrm{t}]-\mathrm{s}$ $>t s j e j H>$ jì were names of the Panicum miliaceum plant in the Old Chinese period, and that the former term referred to glutinous varieties. The character shǔ 乘 is very old. Its graphic precursor is thought to occur in the Shang oracular inscriptions, c. 3300-310о BP. Some tokens of the Shang graph include the graph for 'water,' recognizable at the bottom of the modern character 湬. The dictionary Shuōwén Jièzì, compiled c. 100 CE, says that it was a glutinous cereal used to make wine and credits Confucius with the analysis of the graph as 'grain + enter + water': a grain which one seeps in water to make wine. Glutinous grains are indeed well suited for the fabrication of wine. The character shǔ 秋 was used as a semantic component in several other characters with meanings relating to stickiness. That it was a glutinous grain is quite evident; ji 穄 was its non-glutinous counterpart.

As a Chinese character, 穄*[ts][a][t]-s $>t s j e j H>$ jì is more recent than shǔ 㯟: it has left no known traces in the paleographical record. Its oldest textual example appears to be in the Lüshì Chūnqiū, a late 3rd-century BCE text. According to the Eastern Han commentator Gão Yòu, the plant name jì 穄 had two dialect equivalents: a western form qiàn 㯟+[臣+又], Mc khenH in usage in the Guānxī region (west of Hángǔ Pass in the Yellow River Valley, i.e. modern Shaanxi), and an eastern form má 穈, MC mae, from the region of Jìzhōu in modern central Hebei, northern Henan and western Shandong.

\footnotetext{
15 In Modern Tagalog at least, /d/ has a variant [ $\mathrm{c}$ ] in word-final position.

16 Our 2014 fieldwork has uncovered one Formosan instance of a word for sorghum borrowed from a western Malayo-Polynesian source: Tfuye Tsou batayu (Tsou *r goes to $y$ in Tfuye). This cannot be a loan from nearby Saaroa, as was suggested by an anonymous reviewer: the Saaroa word for sorghum is sasaisaLa (our fieldwork).
} 
Guō, an Eastern Jin dynasty exegete $(276-324 \mathrm{CE})$, states that ji 穄 was like shǔ 乘 but non-glutinous. No dialectal origin is assigned by Gāo Yòu or others to ji 穄, which must mean that this was the standard word for non-glutinous Panicum miliaceum in the 3 rd century CE. There is no earlier-known term. Panicum miliaceum was very prominent in early Chinese agriculture (Bray, 1981) and throughout the Chinese neolithic. Moreover, non-glutinous varieties were more commonly consumed as food, the glutinous forms being reserved for special purposes. It is not plausible, then, that the late date of occurrence of the term ji 穄 in Chinese texts indicates the cereal's absence before the 3 rd century вСЕ. Yet the lower textual profile of ji 穄, compared with its glutinous counterpart shǔ 乘 and with Setaria italica jì 稷, poses a problem, pointed out by one anonymous reviewer. We suspect that it is due to the more rustic nature of non-glutinous Panicum miliaceum compared with the other two. Especially shǔ 秋 glutinous Panicum is used in wine-important in religious ceremonial; Bray, 1981 - and in the preparation of sweets. Setaria italica was also used in religious ceremonial. On the other hand, the term $\mathrm{ji}$ 穄 is absent in early literature because this literature (in particular the Book of Odes, where other cereal names are otherwise common) reflects the life and concerns of the upper strata of early Chinese society.

The character ji 穄, the name of Panicum miliaceum, is composed of the phonetic element jì 祭 'sacrifice' (v. and n.) and the semantic element hé 禾, which occurs in cereal plant names. Baxter and Sagart (2014) reconstruct $P$. miliaceum ji 穄 as Old Chinese *[ts][a][t]-s, with three pairs of brackets. The first indicates the possible presence of an undetected preinitial element before initial *ts-, just as it does in S. italica (see fn. 7); the second warns that the vowel may also have been *e; the third underlines the ambiguity in the consonantal ending: Middle Chinese - $j H$ in a word written with phonetic ji 祭 can reflect oC ${ }^{*}$-t-s, ${ }^{*}$-p-s, and — as Baxter and Sagart (2014) propose - ${ }^{*}$-r?-s or *-n?-s in a late Old Chinese dialect spoken around present-day Hubei. One source of late Old Chinese *-n? itself is early Old Chinese *-r?. Middle Chinese had a stratified pronunciation with layers originating in different late Old Chinese dialects. Thus ji 穄 (oc *[ts][a][t]-s, MC tsjejH) 'Panicum miliaceum, non-glutinous' may represent the regular evolution in that dialect of an early oc *[ts]ar?-s or *[ts]er?-s. If so, ji 穄 is a good phonological match for Proto-Austronesian *baCaR; if it reflects oc *-t-s or *-p-s, it is not. There is unfortunately no way of resolving the issue based on the evidence currently at hand. 
This paper has shown that, of the five Proto-Austronesian reconstructions proposed in the literature for domesticated millet plants, three must be rejected: *baSaR, proposed by Li for Panicum miliaceum, crucially relies on Formosan words which really reflect Proto-Austronesian *baSaw 'to cool off, of cooked cereals'; *baCaj, proposed by Blust for the same domesticate, ignores the shift from Panicum miliaceum to sorghum in the western Malayo-Polynesian world and takes a borrowed Philippine word for 'sorghum' as a true cognate of an inherited, but isolated, Formosan form; and Dempwolff's *zawa 'millet,' later taken by Blust to be a Proto-Austronesian word for Setaria italica, was probably the name of a Sumatran or Javanese variety of Setaria italica which spread to the Philippines, and further to the Formosan language Puyuma. The two remaining terms, *beCey and *baCaR, unambiguously refer to Setaria italica and Panicum miliaceum, respectively, in Austronesian languages (with widespread transfer of meaning to 'sorghum' and 'maize' outside of Taiwan in the case of *baCaR). They are evidently the Proto-Austronesian names of the two millet plants. On the Chinese side, we have shown that the Old Chinese words

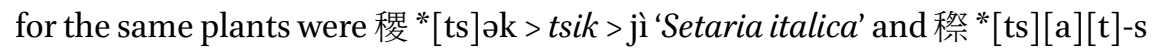
$>t$ sjejH $>$ jì 'Panicum miliaceum, non-glutinous,' although the phonetic merger of the two forms beginning in the 1oth century CE in northeastern China has led to the old name for Setaria italica being widely reinterpreted as a graphic and phonetic variant of the word for Panicum miliaceum in the literature over the past thousand years. There is a good phonological match between the ProtoAustronesian and Chinese words for Setaria italica, according to the SinoTibetan-Austronesian sound correspondences presented in Sagart (2005). The two words for Panicum miliaceum are also matched according to the same set of correspondences, assuming that the traditional pronunciation Middle Chinese $t$ sjejH represents a late Old Chinese dialect form *[ts]at-s or *[ts]et-s going back to early Old Chinese *[ts]ar?-s or *[ts]er?-s. With the exception of two other cereal-related terms and the name of the pine tree, there appear to be very few other names of plant species that are reconstructible to Proto-SinoTibetan-Austronesian. The reason for the preservation of just these few terms is in all likelihood in the economic value of their referents-the pine tree produced fuel and resin.

Thus, the speakers of both Proto-Austronesian and Old Chinese had words for, and knowledge of, two domesticated millets: Setaria italica and Panicum miliaceum. The only area in the world where the two millets were cultivated together before PAN times-say, before 4000 вСЕ-is northeastern China. This places the pre-Austronesians there, adjacent to Henan, the probable Sino- 
Tibetan homeland (Janhunen, 1996; Thurgood, 2008). The Austronesian and Chinese words for Setaria italica fit the sound correspondences described in Sagart (2005). This holds for Panicum miliaceum too, but the argument is more tenuous and conditional than with Setaria. It could be argued that the sound similarities between the Chinese and Austronesian millet terms are the result of contact, indeed that the sixty or so basic vocabulary items exhibiting the sound correspondences in Sagart (2005) are the result of contact. That would then pose the question of the nature of the genetic continuity uncovered by Ko et al. (2014).

In this paper we have deliberately left aside the role played by rice in the neolithic expansion that led to the Austronesian family. Although rice accompanied the millets in neolithic sites in both northeastern China and Taiwan, the names of the rice plant in Sino-Tibetan and Austronesian have not so far been shown to be related. We will return to that question elsewhere.

\section{References}

Baxter, William H. and Laurent Sagart. 2014. Old Chinese:A New Reconstruction. Oxford/ New York: Oxford University Press.

Bellwood, Peter. 2008 [2005]. First Farmers: The Origin of Agricultural Societies. London: Blackwell.

Bellwood, Peter. 2013. First Migrants: Ancient Migration in Global Perspective. Chichester/Malden, MA: Wiley-Blackwell.

Benedict, Paul K. 1942. Thai, Kadai and Indonesian: A new alignment in Southeastern Asia. American Anthropologist, New Series 44: 576-6o1.

Blust, Robert. 1976. Austronesian culture history: Some linguistic inferences and their relations to the archaeological record. World Archaeology 8: 19-43.

Blust, Robert. 1988. The Austronesian Homeland: A linguistic perspective. Asian Perspectives XXVI, $1: 45^{-6} 7$.

Blust, Robert. 1996. Beyond the Austronesian homeland: The Austric hypothesis and its implications for archaeology. In Ward H. Goodenough (ed.), Prehistoric Settlement of the Pacific, 117-140. Philadelphia, PA: American Philosophical Society.

Blust, Robert. 2014. Some recent proposals concerning the classification of the Austronesian languages. Oceanic Linguistics 53(2): 300-391.

Blust, Robert and Stephen Trussel. Ongoing. Austronesian comparative dictionary. Online open access site. Accessible at www.trussel2.com/ACD.

Bray, Francesca. 1981. Millet cultivation in China: A historical survey. Journal d'agriculture traditionnelle et de botanique appliquée 3-4: 291-307.

Bray, Francesca. 1984. Agriculture. [Joseph Needham (ed.), Science and Civilization in China, Vol. 6, part 2.] Cambridge: Cambridge University Press. 
Cauquelin, Josiane. 2015. Nanwang Puyuma-English Dictionary. Language and Linguistics Monograph Series 56. Taipei: Academia Sinica, Institute of Linguistics.

Cense, Anton Abraham and Abdoerrahim. 1979. Makassaars-Nederlands woordenboek. The Hague: Martinus Nijhoff.

Chai, Yan, Huang Yu, and Zhang Xingzan. 1999. 糜子 Meizi [Panicum miliaceum]. Beijing: 中国农业出版社 Chinese Agricultural Editions.

Chang, Kwang-chih. 1980. Shang Civilization. New Haven/London: Yale University Press.

Dempwolff, Otto. 1934-1938. Vergleichende Lautlehre des Austronesischen Wortschatzes. Beihefte zur Zeitschrift für Eingeborenensprachen 19. Berlin: Dietrich Reimer.

Fogg, Wayne H. 1983. Swidden cultivation of foxtail millet by Taiwan aborigines: A cultural analogue of the domestication of Setaria italica in China. In David Keightley (ed.), The Origins of Chinese Civilization, 95-115. Berkeley, CA: University of California Press.

Fuller, Dorian Q. 2011. Pathways to civilizations: Tracing the origins and spread of rice and rice cultures. Rice 4: 78-92.

Gonda, Jan. 1952. Sanskrit in Indonesia. Nagpur: International Academy of Indian Culture.

Gray, Russell D., Alexi J. Drummond, and Simon Greenhill. 20og. Language phylogenies reveal expansion pulses and pauses in Pacific settlement. Science 323: 479-483.

Harlan, Jack R. 1977. The origins of cereal agriculture in the Old World. In Charles A. Reed (ed.), Origins of Agriculture, 357-383. The Hague: Mouton.

Hsing, Yue-ie. 2014. Both Setaria and Panicum were cultivated in Taiwan about five thousand years ago. Paper presented at the Symposium on Dispersion of People, Crops, and Language: Focusing on Millets in Asia, Tachikawa, Japan, March 2014.

$\mathrm{Hu}$, Yangwen 胡錫文. 1984. Su, Shu, Ji, gu mingwu de tantao 粟, 㯟, 稷古名物的探討 [A discussion of the old plant names $S u$, Shu, Ji]. Beijing: Agricultural Editions 農業出 版社.

Janhunen, Juha. 1996. Manchuria: An Ethnic History. Mémoires de la société finnoougrienne 222. Helsinki: Suomalais-Ugrilainen Seura.

Kane, Daniel. 2oog. The Khitan Language and Script. Leiden: Brill.

Ko, Albert Min-Shan, Chung-Yu Chen, Qiaomei Fu, Frederick Delfin, Mingkun Li, HungLin Chiu, Mark Stoneking, and Ying-Chin Ko. 2014. Early Austronesians: Into and out of Taiwan. The American Journal of Human Genetics 94: 426-436.

Li, Hui-lin. 1983. The domestication of plants in China: Ecogeographical considerations. In David N. Keightley (ed.), The Origins of Chinese Civilization, 21-64. Berkeley/Los Angeles/London: University of California Press.

Li, Paul Jen-Kuei. 2004 [1992]. Formosan vs. non-Formosan features in some Austronesian languages of Taiwan. Selected Papers on Formosan Languages, 953-975. Taipei: Academia Sinica, Institute of Linguistics. 
Li, Paul Jen-Kuei. 2015. Linguistic and archaeological evidence for rice and millet in Taiwan. Taiwan Journal of Indigenous Studies 8(4): 1-9.

Li, Paul Jen-Kuei and Shigeru Tsuchida. 2001. Pazih Dictionary. Nankang: Academia Sinica, Institute of Linguistics (preparatory office).

Matthes, Benjamin Frederik. 1859. Makassaarsch-Hollandsch woordenboek. The Hague: Nijhoff.

Sagart, Laurent. 1993. Chinese and Austronesian: Evidence for a genetic relationship. Journal of Chinese Linguistics 21(1): 1-62. [Chinese translation by Zeng Xiaoyu in Shi Feng (ed.), Hanyu Yanjiu zai haiwai, 59-110. Beijing: Yuyanxueyuan, 1995.]

Sagart, Laurent. 1995. Some remarks on the ancestry of Chinese. In William S.-Y. Wang (ed.), The Ancestry of the Chinese Language, Journal of Chinese Linguistics monograph series no. 8, 195-223.

Sagart, Laurent. 1999. The Roots of Old Chinese. Current Issues in Linguistic Theory 184. Amsterdam: John Benjamins.

Sagart, Laurent. 2004. The higher phylogeny of Austronesian and the position of TaiKadai. Oceanic Linguistics 43(2): 411-444.

Sagart, Laurent. 2005. Sino-Tibetan-Austronesian: An updated and improved argument. In Laurent Sagart, Roger Blench, and Alicia Sanchez-Mazas (eds.), The Peopling of East Asia: Putting Together Archaeology, Linguistics and Genetics, 161-176. London: RoutledgeCurzon.

Sagart, Laurent. 2008. The expansion of Setaria farmers in East Asia: A linguistic and archaeological model. In Alicia Sanchez-Mazas, Roger Blench, Malcolm D. Ross, Ilia Peiros, and Marie Lin (eds.), Past Human Migrations in East Asia: Matching Archaeology, Linguistics and Genetics, 133-157. London: Routledge

Sagart, Laurent. 2016. The wider connections of Austronesian-A response to Blust (2009). Diachronica 33(2): 255-281.

Shen, Zhongwei. 2014. The $C h \bar{e}-Z h \bar{e}$ syllables of Old Mandarin. In Richard VanNess Simmons and Newell Ann Van Auken (eds.), Studies in Chinese and Sino-Tibetan Linguistics: Dialect, Phonology, Transcription and Text, 309-329. Taipei: Academia Sinica, Institute of Linguistics.

Stevens, Chris J. and Fuller, Dorian Q. 2017. The spread of agriculture in eastern Asia: Archaeological bases for hypothetical farmer/language dispersals. Language Dynamics and Change $7(2): 15^{2-186 .}$

Stückelberger, Albert and Gerd Grasshoff (eds.). 20o6. Ptolemaios-Handbuch der Geographie. 2. Teilband: Buch 5-8 und Indices. Basel: Schwabe.

Thurgood, Graham. 20o8. Han-Zang Yuyan de Puxi [The Sino-Tibetan languages: Genetic inheritance, external contact and change] (in Chinese). Minzu Yuwen 2: $3^{-}$ 15.

Trung Dictionary Committee. 2016. Concise Trung-English-Chinese Dictionary. Dallas, TX: SIL International. Accessible at http://trung.webonary.org/?lang=en (accessed June 1, 2017). 
Tsang, Cheng-Hwa. 2005. Recent discoveries at a Tapenkeng culture site in Taiwan: Implications for the problem of Austronesian origins. In Laurent Sagart, Roger Blench, and Alicia Sanchez-Mazas (eds.), The Peopling of East Asia: Putting Together Archaeology, Linguistics and Genetics, 63-73. London: RoutledgeCurzon.

Tsang, Cheng-Hwa. 2012. Nánkē kăogǔ fāxiàn de dàomǐ yǔ xiǎomǐ jiānlùn xiāngguān wèntí 南科考古發現的稻米與小米兼論相關問題 [Issues relating to the ancient rice and millet grains unearthed from the archaeological sites in Tainan Science Park]. Journal of Chinese Dietary Culture 8(1): 1-24.

Tsuchida, Shigeru. 1976. Reconstruction of Proto-Tsouic phonology. Study of Languages and Cultures of Asia and Africa Monograph Series 5. Tokyo: Tokyo Daikokugo Daigaku.

Tsuchida, Shigeru. 1977. Some plant names in Formosan languages. Computational Analyses of Asian \& African Languages 7: 79-119.

Verheijen, Jilis A.J. 1984. Plant Names in Austronesian Linguistics. Jakarta: Universitas Katolik Indonesia Atma Jaya.

Weber, Steven, Arunima Kashyap, and David Harriman. 2010. Does size matter: The role and significance of cereal grains in the Indus civilization. Archaeological and Anthropological Sciences 2: 35-43.

Wolff, John U. 2010. Proto-Austronesian Phonology with Glossary. 2 volumes. Ithaca: Cornell Southeast Asia Program Publications.

You, Xiuling 游修龄. 1984. Lun Shu he Ji 论㯟和稷 [On the terms shǔ and ji]. Nongye Kaogu 农业考古 [Agricultural Archeology] 1984(2).

Zhang, Bo 张波. 1984. Du Shi bian ji 读诗辩稷. Journal of the Northwest Institute of Agronomy 西北农学院学报 3: 1-4. 